Original Article

\title{
An input-output-based methodology to estimate the economic role of a port: The case of the port system of the Friuli Venezia Giulia Region, Italy
}

\author{
Romeo Danielis and Tullio Gregori \\ Department of Economics, Business, Mathematics and Statistics, University \\ of Trieste, Trieste, Italy. \\ E-mails:danielis@units.it; tullio.gregori@econ.units.it
}

\begin{abstract}
The article illustrates the results of a research project aimed at identifying the main economic and industrial characteristics of the port system of the Friuli Venezia Giulia (FVG) Region, Italy, and the role it plays within the economy. Combining a top-down and bottom-up approach, based on interviews and detailed data at firm level, a bi-regional input-output (I-O) table is built with a special disaggregation of the 12 port-related sectors of the FVG region. The I-O table provides the basis for the estimation of a bi-regional I-O model. Drawing from the I-O literature, the article also implements two methodologies to estimate: (a) the level of self-sufficiency of the port system and (b) its degree of substitutability, that is, what would happen if the FVG port system closes down, completely or partially.
\end{abstract}

Maritime Economics \& Logistics (2013) 15, 222-255. doi:10.1057/mel.2013.1

Keywords: port economics; port impact studies; input-output model; inputoutput table; maritime transport; shipping

\section{Introduction}

Estimating the economic role of a port is a relevant topic both in the political and in the scientific debate. ${ }^{1}$

In the political debate, the estimate of the direct and indirect economic significance of a port is often used to motivate the request for public

(C) 2013 Macmillan Publishers Ltd. 1479-2931 Maritime Economics \& Logistics Vol. 15, 2, 222-255 www.palgrave-journals.com/mel/ 
funds for building new port infrastructure or to justify its social costs, such as expropriation of land, pollution, noise, community severance and so on. Such estimate is usually commissioned by a Port Authority or a local government.

In the scientific debate, the evaluation of the economic role of a port is also of interest since it allows to compare among different ports (for example, gateway ports versus trans-shipment ports, European versus North American ports, Northern-range ports versus Mediterranean ports, specialized versus unspecialized ports) and to trace the historical evolution of a port, for instance, as it changes from the eighteenth century 'emporion'2 nature to the nineteenth and twentieth century commercial nature, from handling only conventional cargo to handling mostly containers, and so on.

Nevertheless, the evaluation of the economic role of a port is fraught with difficulties that are discussed at length in the literature and that are not completely solved, yet.

The article presents in the section below an extensive literature review of such difficulties, of the methodologies used to estimate the role of a port and of their most recent applications. The next section summarizes the main features of the ports of the Friuli Venezia Giulia (FVG) Region, Italy, explains the research motivation, the research methodology and illustrates the main results. A specific section illustrates a methodology, developed within an input-output (I-O) framework, to estimate the degree of technological self-sufficiency of a port and its economic importance and illustrates the results obtained by applying such a methodology to the FVG port system. A final section concludes.

\section{Literature Review}

As pointed out in former reviews (Waters, 1977; Chang, 1978; Davis, 1983; Gripaios and Gripaios, 1995), regional port impact studies are used not only to inform the general public on the importance of port services to the region's economy, but also as a public relations tool. However, 'the differences in methodologies adopted to define and measure various types of socio-economic impacts sometimes lead to misconceptions as well as misleading comparisons across ports within and between regions' (Dooms et al, 2011, abstract, p. 1). Hence, it is very important for the researcher to be conscious of which methodologies could be used to estimate the role of a port in an economy and which are their main pros and cons. The following paragraphs summarize the relevant literature on these topics.

Port impacts on the economy are measured to assess the economic and social impacts (direct, indirect and induced) of ports on their respective hinterlands or forelands. Ports are seen as economic catalysts for the regions they

\footnotetext{
(C) 2013 Macmillan Publishers Ltd. 1479-2931 Maritime Economics \& Logistics Vol. 15, 2, 222-255 223
} 
serve, where the aggregation of services and activities generates benefits and socio-economic wealth. The performance of a port is depicted in terms of its ability to generate maximum or optimal output and economic wealth.

Bichou (2007) lists three main methodologies that have been used to evaluate the economic impact of a port: I-O, computable equilibrium and gravity models. For more recent classifications see Pallis et al (2009) and Coto-Millán et al (2010a).

The US MARAD's Port Economic Impact Kit (PortKit), developed by the Maritime Administration of the US Department of Transportation, is considered the most comprehensive and regularly updated I-O port model (Little, 1979; Temple et al, 1985). The Port Kit - released in December 2000 - is a selfcontained, PC-based model that has been developed to help US deep-draft ports and other organizations explain the value of the port industry and port facility investments to their communities. It uses a user-friendly, menu-driven format, model to assess the economic impact of maritime-related construction and ongoing activities at the national, state and local level. It comprises a 30-sector I-O table - with up-to-date portrayals of key maritime sectors. Ongoing maritime activities modelled in the PortKit include container, liquid and dry bulk, break bulk, auto transport, cruise, project cargo, and passenger ferry operations. The PortKit considers all activities directly needed to handle each specific movement. Maritime construction and dredging are also included in the model. Hamilton et al (2000) developed similar software versions for the US rural inland waterways.

The National Technical Information Service (2000) even produced a guide for the proper use of economic impact assessment models necessary for analysing the economic outcome of transportation projects, including ports. It argues that these models can range from the relatively inexpensive and fairly simple Regional I-O Modeling System, to the moderately complex Minnesota IMPLAN I-O model, to the most sophisticated and expensive integrated I-O-econometric models of analysis typified by the widely used proprietary Regional Econometric Modeling, Inc. (REMI) software. Their aim is to provide transport managers, operators and planners with a well-researched and simply presented comparative economic impact assessment guidebook for using each of these tools.

Typically, the I-O model in a port impact study is used to calculate indirect effects (Haralambides, 1996; Hughes, 1997). For instance, EconSearch Pty Ltd (2001) measures the economic impact of port-related activity defined as the activity undertaken by firms and organizations in moving cargo through the Port of Esperance. This is measured in terms of output, value added, household income and employment. The estimates cover the direct effects of the port and the subsequent flow-on effects to other sectors of the regional economy using 
an I-O table. Similar applications are performed by the Urban Center of the Cleveland State University (1997) and the Bureau of Transport Economics (2000).

Port I-O models are also used to assess impacts of existing port facilities (Moloney and Sjostrom, 2000) or to justify future port investments (for example, Braun, 1990; Le Havre Port, 2000). Braun et al (2002) focus on the role of the cruise industry in the US economy. They measure the direct spending of the cruise industry, and use a regional I-O model to estimate the total economic impact. The impacts are based on survey data for the following three groups: cruise line spending, cruise passenger spending and ships' crew spending. Similarly, Moloney (2004) utilizes a survey of cruise liner tourists visiting qIreland through the Port of Cork to assess the scale and variety of spending by these tourists. These expenditures are then applied to an I-O model of the Irish economy to establish the direct, indirect and induced expenditures, as well as the employment effects of this spending.

Coppens et al (2007) make an interesting attempt to estimate the economic relevance for a region or for the national economy at a disaggregate level by identifying, quantifying and locating the mutual relationships between the various port players themselves and between them and other Belgian industries. They perform a sectoral analysis by compiling a regional I-O table using a bottom-up approach and identifying the main customers and suppliers of the port's key players or stakeholders. In so doing, the economic impact of the port is quantified, both functionally and geographically. They find, in the case of the port of Antwerp, important links between freight forwarders and agents. The geographical analysis suggests the existence of major agglomerating effects in and around the port of Antwerp, referred to as a major transhipment location point. Coppens et al (2007) is the primary source of inspiration for the work presented in this article.

Since the limitations of the I-O model are well-known - that is, production functions with constant technology, lack of scale economies and non-input substitution in the process of production (Francou et al, 2007) - an alternative is to resort to computable equilibrium (CGE) models. These models have a level of disaggregation that allows structural change analysis, but also capture the interdependent nature of production, demand and trade within a general equilibrium framework. They incorporate market mechanisms and price incentives. The first application of this methodology to port analysis is due to Doi et al (2001). They use a CGE model developed for the year 1995 to analyse the system-wide impact of increased efficiency of ports in Japan. They consider three transportation sectors: shipping, port operations and other transportation. All sectors are assumed to be perfectly competitive and operate under constant returns to scale. Production technology is modelled by nested CES functions.

\footnotetext{
(C) 2013 Macmillan Publishers Ltd. 1479-2931 Maritime Economics \& Logistics Vol. 15, 2, 222-255 225
} 
It is also assumed that there are three factors of production: labour, capital and sector-specific fixed intermediate inputs. Labour supply is determined by a variable linear expenditure system and labour moves freely between sectors. Hence, there is a single equilibrium wage rate in the economy. Total capital stock is fixed and also capital is free to move among sectors. They find that technological efficiency in ports reduces the cost of ocean transportation, and that the forward and backward linkages of imports and exports introduce some positive gains in the national GDP. They also find that spill-over effects are substantial on ocean transportation and to a lesser extent on the Japanese economy.

Haddad et al (2010) use a spatial CGE model to elucidate one of the mechanisms that link trade barriers, in the form of port costs, subsequent growth and regional inequality. The spatial CGE model is integrated to a transport network system. The role of ports of entry versus ports of exit is explicitly considered. Measures of efficiency for different port locations are incorporated in the calibration of the model and used as a benchmark in simulations. Three scenarios are evaluated: an overall increase in port efficiency in Brazil to achieve international standards; efficiency gains associated with decentralization in port management in Brazil; and regionally differentiated increases in port efficiency to reach the boundary of the national efficiency frontier.

A further methodology is to use gravity models. Wilson et al (2003), for instance, analyse the relationship between trade facilitation, trade flows and economic development in the Asia-Pacific region for the goods sector. Four indicators of trade facilitation are used: port efficiency (to capture the quality of infrastructure of maritime and air ports), customs environment, regulatory environment and electronic-business usage. The authors find that enhanced port efficiency has large and positive effects on trade.

In addition to the methodological debate, there is also a debate concerning the definition of what a port is or, more specifically, which industrial activities are part of a port and which geographical boundaries does a port have.

In fact, in a port perimeter many activities are performed. Some of them are typically transport-related, such as ship loading and unloading operations, ship operations and services (agencies, pilotage, towage and bunkering), land transport, logistics activities, cargo services (for example, freight forwarding and customs broking). Some others such as industrial production of (petro)chemical, iron and steel, automotive, engines, energy, ships and food products and service and government agencies are located within the port perimeter or in the surrounding areas for convenience or for historical reasons. Which of these and how should be considered in a port impact study?

Yochum and Agarwal $(1987,1988)$ distinguish between required and induced industries. Required industries are those necessary to the movement 
of waterborne commerce and are fairly easy to define. They are included in all port impact studies to assess direct impact. Induced industries are much more troublesome, since they are defined as those firms that have been able to expand their markets by using a particular port. The port is seen as a source of reduced transportation cost and a magnet for their competitiveness. However, they could locate in the region regardless of the availability of port facilities. Hence, it is not so clear whether and how they should be included. A complete inclusion might lead to an overestimation, and insufficient inclusion to an underestimation. Following Davis (1983), Yochum and Agarwal (1987, p. 76) deem essential to investigate the degree of port dependency and they see 'no easy way around this problem other than an extensive survey of firms and government institutions to ascertain the proportion of their workforce devoted to the movement of cargo through the port'. They provide in Table 1 of their paper a list of the main activities and the percentage of total employment that is transport related in their case study.

The distinction between port and non-port-related industries is taken one step further by Musso et al (2000) who claim that the crucial question is not 'if' but 'to what extent' an industry is port related. They implement and test a methodology estimating the probability of the relationship, using location quotients and control region techniques.

As regards uncertainty about the geographical boundaries of a port, influential papers by Notteboom and Rodrigue (2005), Notteboom (2008) and Rodrigue and Notteboom (2009) point out that a port is just a node in a global supply chain. The functioning and the competitiveness of a port depends on its relationship with the hinterland. A port is not simply to be considered the set of activities taking place in the port perimeter, as many crucial activities (such as storing areas, distribution centres or service activities) take place in the surrounding areas, in the seaport hinterland and or in metropolitan areas. These ideas are also discussed by Bichou and Gray (2005), Mangan et al (2008), Notteboom (2010), and Vitsounis and Pallis (2010). Trying to operationalize the above suggestions, Verbeke and Dooms (2008) propose an integrative framework and an operational model to be used for long-term strategic port planning. They come to the conclusion that in spite of only limited potential for additional direct employment in the port area itself (due to the continued containerization phenomenon), there exist a large potential for employment creation in the port network (Verbeke and Dooms, 2008, p. 5). They estimate that the employment impact outside the port area is almost twice as large as the one inside the port area itself.

Further discussion exists on the validity of the above methodologies, particularly the one applying the I-O model. DeSalvo (1994, p. 33), for instance, argues that 'port economic impacts are mis-estimated because impact studies

\footnotetext{
(C) 2013 Macmillan Publishers Ltd. 1479-2931 Maritime Economics \& Logistics Vol. 15, 2, 222-255 227
} 
Table 1: Throughput of the port of Trieste (2002-2007)

\begin{tabular}{|c|c|c|c|c|c|c|}
\hline & 2002 & 2003 & 2004 & 2005 & 2006 & 2007 \\
\hline Break bulk (tons) & 9135153 & 8462722 & 9265688 & 8913506 & 8425006 & 9234636 \\
\hline Dry bulk (minerals, coal, grains) (tons) & 2479152 & 1783138 & 737522 & 839415 & 1977314 & 2114609 \\
\hline Liquid bulk (crude oil, mineral oil) (tons) & 35559558 & 35752000 & 36835811 & 37965410 & 37765398 & 34766830 \\
\hline Annual cargo tonnage & 47173863 & 45997860 & 46905835 & 47718331 & 48167718 & 46116075 \\
\hline Containers (in TEU) & 185301 & 120438 & 174729 & 198319 & 220310 & 265863 \\
\hline Containers (full cont. in tons) & - & - & 1880412 & 2314304 & 2397942 & 2832064 \\
\hline Ro-Ro/ferry (tons) & NA & NA & 6221443 & 5320351 & 5680786 & 6053645 \\
\hline No. of trucks on Ro-Ro/ferry & NA & NA & 229390 & 197115 & 207378 & 225656 \\
\hline General cargo ships (tons of general cargo) & - & - & 256561 & 192178 & 445774 & 658372 \\
\hline Passengers (no.) & - & - & 303490 & 90523 & 103408 & 113702 \\
\hline
\end{tabular}

Source: Port Authority of Trieste. 
fail to consider the price changes and the resulting changes in local-area production that would occur in the impact area were the local port unavailable for the handling of imports and exports'. He proposes to use supply-demand analysis to obtain the conceptually correct impact, and also proposes an operational formula to be used with five direct-impact categories: port industry, exports, non-comparable imports, comparable imports and inland transportation.

Hall (2004a, b), on the basis of the widely quoted estimate of the cost of the West Coast port 10-day lockout in fall 2002, which he judged vastly overinflated, reviews port impact studies stating that they do not adequately address the possibilities for substitution, even in the short run. The reason being, in his view, 'because port impact studies are poorly designed to deal with the changing nature of the relationship between seaport operations and regional economic development' (Hall, 2004a, p. 355).

Given that the recognized structural weaknesses of economic impact studies that rely on the I-O approach lie in their static character, Castillo et al (2007) proposed a way to solve this problem by linking the I-O model to a system dynamics simulation framework supported by econometric estimations of some important variables.

Ferrari et al (2010) review port impact studies ${ }^{3}$ and argue that there is a sort of paradox, for 'as ports - and their efficiency - increase their importance for economic development, their role for the economic system of which they are part decreases'. Such a decrease is due, in their view, to the continuing reduction of the cost of land transport in real terms; to the creation of custom unions; to the development of the logistics industry; and to cargo unitization. These changes have made the port production function more capital- and landintensive; they have produced the progressive overlapping of port hinterlands together with de-maritimization. In the above-mentioned paradox lies the importance recently acquired by surveys conducted on the economic impact of ports. 'In other words, the importance of shifting from a microeconomic point of view founded on port efficiency, which is useful for a port's users, to macroeconomic assessments of labour, investments and income, which are useful for the port's community' (Ferrari et al, 2010, p. 10).

Coto-Millán et al (2010b) represent one of the first attempts to estimate the economic impact of the Port of Santander not on a region but on the economy of the city of Santander, Cantabria, and its hinterland in 2005.

Dooms et al (2011) present a meta-analysis of 33 socio-economic impact studies conducted for seaports. They conclude that there is 'a great diversity in terms of measures of economic impacts, basic assumptions and methodologies used, leading to important differences between communicated impacts of port activity' (Dooms et al, 2011, p. 12). With reference to the discussion on

\footnotetext{
(C) 2013 Macmillan Publishers Ltd. 1479-2931 Maritime Economics \& Logistics Vol. 15, 2, 222-255 229
} 
the alleged misuse of socio-economic impacts (Hall, 2004a,b; Crompton, 1995, 2004, 2006), they stress the proper inclusion of regional impacts in the port hinterland and logistics network. They also point out that very few countries or regions collect or compile these analyses in a systematic way. As an example of best practice they quote Belgium, where the Belgian National Bank produces a publicly available annual report on the socio-economic impacts of ports, accepted by all stakeholders and used in most socioeconomic analysis of port projects. Further recent port impact studies include Haezendonck et al (2000), Bryan et al (2006), Guerrero et al (2008), Acciaro (2008), Acosta et al (2010).

\section{An Estimate for the Port Cluster of the Friuli Venezia Giulia Region, Italy}

In this section, we illustrate the results of a port impact study for the FVG Region, located in the North-east of Italy, that - with reference to the criteria set by Dooms et al (2011) - has the following characteristics: it combines both a top-down and bottom-up approach; it builds a bi-regional I-O table and makes use of a bi-regional I-O model; it is based on ad hoc surveys; it estimates both direct (employment, output, value added) and indirect impacts. It does not set specific geographical boundaries; it encompasses several ports, aggregated into a single port system; it provides information on the sectoral boundaries. Furthermore, the substitution issue is dealt with within the I-O framework.

\section{The ports of Friuli Venezia Giulia}

The FVG Region, an Italian region located on the north east of Italy and bordering with Austria and Slovenia, utilizes three ports: Trieste, Monfalcone and Porto Nogaro. They form what we have called the FVG port system. They are all situated in the North Adriatic and, geographically and historically, serve the North East of Italy and the so-called Mittle-European countries, that is, southern Germany, Austria, Hungary and the Czech Republic (Figure 1).

Geographically, the port of Trieste is conveniently located. It lies 1294 nautical miles away from Suez (Port Said), equivalent to 2 days and 16 hours of sailing at 20 nautical miles, whereas the Northern European range ports are 3.527 nautical miles away, equivalent to 7 days and 8 hours of sailing at 20 nautical miles. The distances from the port of Trieste of some of the main surrounding cities is as follows: Milan $411 \mathrm{~km}$, Munich $480 \mathrm{~km}$, Graz $288 \mathrm{~km}$, Budapest $539 \mathrm{~km}$, Vienna $472 \mathrm{~km}$, Prague $865 \mathrm{~km}$, Zagreb $222 \mathrm{~km}$. The port has 


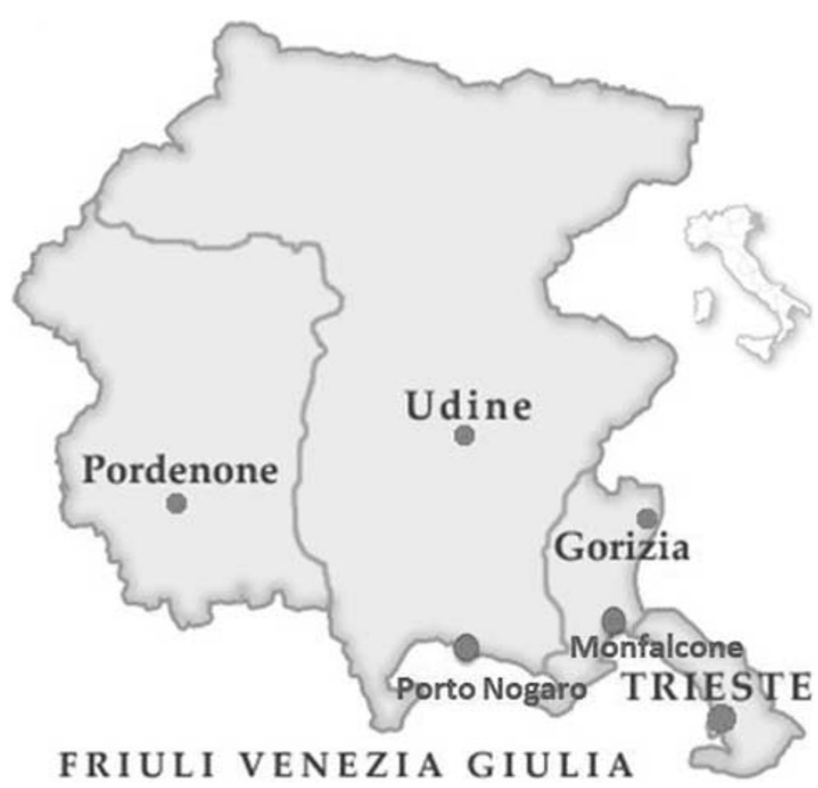

Figure 1: The Friuli Venezia Giulia port system.

an adequate draft of minimum $18 \mathrm{~m}$ along the quays. The total available area is $2.3 \mathrm{~km}^{2}$ (of which 1.8 customs free); the area available for storage is equal to $925.000 \mathrm{~m}^{2}$ and the total quay-length is equal to $12 \mathrm{~km}$. The port is divided into five sections, two of which are dedicated to industrial activities, including the Trieste-Ingolstadt pipeline.

The throughput, in terms of tons, of the port of Trieste (Table 1) has been rather stable between 2002 and 2007, with a large component of liquid fuel. The share of containers is growing but still small in absolute terms. Ro-Ro/ferry transport of trucks from Turkey is quite significant.

The port di Monfalcone, which lies closer to the hinterland than Trieste, has an area of $0.68 \mathrm{~km}^{2}$ with a draft varying between 9.5 and $11.7 \mathrm{~m}$. Various industrial activities are located nearby, including the Monfalcone Shipyard belonging to Fincantieri Spa, the largest Italian shipyard. The port specializes in general- and dry bulk cargo such as kaolin, coal, cellulose, cement, grains, wood, machinery, minerals, stones, steel and iron, iron scraps, and vehicles. In 2007 the port throughput was 4411900 tons.

The port of Nogaro operates nearby the river Corno. It is rather small (1.2 km quay-length) and with draft of between 4.5 and $7.5 \mathrm{~m}$. It benefits a large hinterland area and it serves the metallurgical and wood industries located nearby. In 2007 its throughput was 1455000 tons.

(C) 2013 Macmillan Publishers Ltd. 1479-2931 Maritime Economics \& Logistics Vol. 15, 2, 222-255 231 


\section{Motivations and methodology}

The aim of this research is to answer two questions:

1. Which are the main economic and industrial characteristics of the FVG port system?

2. What is the economic role of the FVG port system?

With regard to the first question, the research identifies the number and type of firms that are part of FVG port system; which and how many type of activities they perform; how many people they employ; which is their output and their value added; where are they located and how many locations they have; and what is their profitability.

A choice is made of focusing only on goods transport activities, disregarding passengers, although some firms are concerned, and some infrastructures are used, also for passenger transport and cruises.

In order to identify the role that the FVG port system plays in the economic system, we decided to use an economic accounting scheme known as intersectoral table, along the lines of the one built by the Italian Bureau of Statistics (ISTAT) for the Italian economy. Since the focus is on port-related activities, 12 port-related sectors are identified and estimated. In the national I-O tables, port activities are included into two separate sectors, that is, maritime transport and supporting and auxiliary transport services. The result is a bi-regional (FVG-Other Italian Regions, hereafter, OIRs), 22 sector I-O table estimated for the year 2007. Sectors 1-12 are related to port activities performed in the FVG port system, sectors 13-17 are non-port-related activities performed in FVG and sectors 18-22 refer to activities performed in the OIRs.

The main research questions that can be answered by an I-O table $\backslash$ model are the following: (a) which interdependencies exist between the sectors of economic activity, or in what amount each sector buys $\backslash$ sells goods and services from any other sector? (b) Which exchanges take place within the FVG region, between the FVG region and the OIRS and between the region FVG and the Rest of the World (hereafter, RW)? (c) In case of an increase in demand for a good or service produced by a sector of activity, which are the direct, indirect and induced impacts on production, employment and income at the aggregate level and for each sector and geographical area?

\section{Economic and industrial features of the regional port system}

As discussed above, identifying the geographical boundaries of a port is inevitably controversial. In this research we opted for a pragmatic solution. 
We identify the firms belonging to the FVG port system as those who are authorized by the port authorities to enter the port perimeter. Such firms include six typologies:

1. Firms authorized to carry out port and service operations according to the Articles 16, 17 and 18 of the 84/1994 port law.

2. Firms authorized to operate within the port perimeter according to Article 68 of the Italian Navigation Code.

3. Inland transport firms not included under Article 68 of the Italian Navigation Code.

4. Freight forwarders and maritime and custom agents.

5. Firms providing general services and port services (pilotage, towing, mooring and hauling services).

6. Public agencies who, in various ways, manage and control the operations of a port and the movement of goods (Customs, Coast Guard, Police, Maritime Health authority, Port Authority, Veterinarian, Fire brigade).

The total number of authorized firms in 2007 is 480, that can be subdivided into four macro-sectors or 16 sectors (Table 2).

Table 2 shows that only 66.6 per cent of the firms that operate in the FVG port system perform transport-related activities, while 34.4 per cent perform industrial, construction, commercial or service activities. These data indicate that ports are not only areas where goods are moved, but have a complex and multi-faceted industrial nature. A finer disaggregation is presented in Table 3, with 12 port, maritime and transport activities and four non-transport-related activities.

Firms locate mainly or exclusively within or outside the port perimeter. Based on the available information, we find that only 26.5 per cent of the firms are located exclusively within the port perimeter, 31.7 per cent are located also within the port perimeter and 41.9 per cent are located outside the port perimeter. This indicates that one cannot understand what a port is, only by

Table 2: Firms per macro-sector in 2007

\begin{tabular}{lcr}
\hline Macro-sectors & Number & Percentage \\
\hline Port-related firms & 244 & 50.8 \\
Inland transport firms & 69 & 14.4 \\
Maritime transport firms & 2 & 0.4 \\
Non-transport-related firms & 165 & 34.4 \\
Total & 480 & 100.0 \\
\hline
\end{tabular}


Table 3: Firms per sector in 2007

\begin{tabular}{lrrrrr}
\hline Sector & Number & Percentage & Monfalcone & Porto Nogaro & Trieste \\
\hline Agents & 37 & 7.7 & - & 2 & 35 \\
Forwarders & 75 & 15.6 & 11 & 5 & 59 \\
Shipping companies & 2 & 0.4 & - & 1 & 2 \\
Terminal operators & 19 & 4.0 & - & 1 & 15 \\
Public agencies & 9 & 1.9 & 4 & - & 8 \\
Road transport & 66 & 13.8 & 1 & - & 2 \\
Railways & 3 & 0.6 & 1 & - & 3 \\
Port services & 4 & 0.8 & 1 & - & 61 \\
General services & 62 & 12.9 & - & - & 20 \\
Services to ships & 9 & 1.9 & 1 & - & 6 \\
Labour pools & 22 & 4.6 & 7 & 1 & 61 \\
Services to goods & 7 & 1.5 & 1 & - & 31 \\
Manufacturing & 68 & 14.2 & 2 & 12 & 45 \\
Construction & 32 & 6.7 & 1 & & 16 \\
Commerce & 48 & 10.0 & 35 & 433 \\
Services & 17 & 3.5 & & & - \\
\end{tabular}

looking at what happens within its area, as the literature on port regionalization suggests.

Next, direct employment, output and value added are estimated. This is done on the basis of direct interviews and on the information contained in the firm's income and financial statements for the year 2007. The statistical coverage is presented and discussed in Monte (2011).

Direct employment is estimated on the basis of a question asked directly, by telephone or in person, to each firm about the number of people directly employed in port activities in the port perimeter. The overall figure is between 5353 and 8243 people. The former figure considers only people employed in activities strictly performed in the port perimeter, the latter figure adds the people employed in the activities performed in port-related firms in the FVG Region but outside the port perimeter (for example, administrative jobs performed in town offices). The 5353 people employed in the FVG port system are distributed as follows: maritime and custom agents: 3 per cent; freight forwarders: 10 per cent; shipping companies: 4 per cent; terminal operators (stevedores): 11 per cent; public agencies: 18 per cent; road transport and logistics companies: 8 per cent; railway companies: 3 per cent; port services (pilotage, towing, mooring and hauling services): 3 per cent; general services: 7 per cent; services to the ships including bunkering: 1 per cent; labour services (labour pools ex art. 68): 9 per cent; services to goods (general and chemical control): 
0.2 per cent; manufacturing: 16 per cent; constructions: 2 per cent; commerce: 3 per cent; services: 1 per cent.

Total (direct + indirect) employment of the FVG port system is estimated via a methodology applied to the bi-regional I-O model. The figure depends on which assumptions are made. Under the extreme assumption of total port closure and substitution of the demand currently satisfied in the FVG port system by foreign imports the total loss for the entire national economic system is equal to 11443 people. This is a specific feature of this research that is discussed in detail below.

The estimate of FVG port system's output poses an additional difficulty since many firms are multi-activity and multi-branch, so that output is produced jointly by branches located in the FVG port system and outside the FVG port system (in the FVG or outside). Since direct information on how to subdivide the firms' output between activities and branches was rarely available, the estimate required the introduction of some assumptions. We assumed that the output of a firm with many branches could be distributed among them proportionally to the number of people employed in each one, corrected by a factor of 1.2 in order to attribute a larger share to the branches where the activity takes place, rather than to the headquarters where the administrative and directional activities are performed. Such a correction factor is based on informal evidence collected during interviews with firm managers. The results are presented in Table 4.

It can be seen that the 480 firms operating in the FVG port system realize their revenue mainly outside the port system and mainly in non-transportrelated activities. In this sense the port system can be defined as an open economic system. Such a conclusion is strengthened when the same analysis is performed on value added. The results are illustrated in Table 5.

It can also be observed that total value added of the FVG port system, which is equal to 330 million euros, derives mainly from transport-related activities but almost one-third of it is generated by non-transport-related activities. More in detail, the value added generated by transport activities can be subdivided

Table 4: Total revenue of the firms authorized to work in the FVG port system in 2007 by type of activity performed and location

\begin{tabular}{lccc}
\hline & $\begin{array}{c}\text { Revenue produced within the FVG } \\
\text { port system }\end{array}$ & $\begin{array}{c}\text { Revenue produced within the } \\
\text { FVG region }\end{array}$ & Row total \\
\hline $\begin{array}{l}\text { Transport-related } \\
\text { activities }\end{array}$ & $1552(30 \%)$ & $387(8 \%)$ & $1939(38 \%)$ \\
$\begin{array}{c}\text { Non-transport-related } \\
\text { activities }\end{array}$ & $428(8 \%)$ & $2752(54 \%)$ & $3180(62 \%)$ \\
Column total & $1980(39 \%)$ & $3139(61 \%)$ & $5119(100 \%)$ \\
\hline
\end{tabular}


Table 5: Value added of the firms authorized to work in the FVG port system in 2007 by type of activity performed and location

\begin{tabular}{lccc}
\hline & $\begin{array}{c}\text { Revenue produced } \\
\text { within the FVG } \\
\text { port system }\end{array}$ & $\begin{array}{c}\text { Revenue } \\
\text { produced within } \\
\text { the FVG region }\end{array}$ & Row total \\
\hline Transport-related activities & $238(18 \%)$ & $183(14 \%)$ & $420(32 \%)$ \\
Non-transport-related activities & $92(7 \%)$ & $796(61 \%)$ & $888(68 \%)$ \\
Column total & $330(25 \%)$ & $978(75 \%)$ & $1309(100 \%)$ \\
\hline
\end{tabular}

as follows: maritime and customs agents: 3.2 per cent; freight forwarders: 11.8 per cent; shipping companies: 5.6 per cent; terminal operators: 11.2 per cent; public agencies: 22.1 per cent; road transport and logistics companies: 9.6 per cent; railway companies: 5.1 per cent; port services (pilotage, towing, mooring and hauling services): 8.6 per cent; general services: 9.5 per cent; services to the ship including bunkering: 1.5 per cent; labour services (labour pools, warehouse workers): 9.6 per cent; services to the goods (general and chemical control): 0.6 per cent; manufacturing: 0.7 per cent; construction: 0.0 per cent; commerce: 0.7 per cent; services: 0.1 per cent. The large percentage generated by the public agencies deserves special mention.

Moreover, it can be observed that many firms are part of a group that operates in other ports and other regions as well (percentage-wise they are 46 per cent in terms of number and 88 per cent in terms of revenue). Thirtyseven per cent of the firms have more than one branch. Ninety per cent of the firms have their registered office in the FVG, but some have their registered office abroad. The conclusion that the FVG port system is a very open economic system is confirmed when one looks at where the input suppliers and the clients are located. The FVG port system buys 50 per cent of its inputs abroad, 42 per cent in OIRs and only 8 per cent in FVG. It sells 29 per cent of its services within the FVG region, 36 per cent in OIRs and 34 per cent abroad.

From the income and financial statements of the firms located in the FVG port system, five financial indicators can be estimated (Table 6): EBITDA/R (earnings before interest, taxes, depreciation and amortization on revenues), return on sales (ROS), return on asset (ROA), return on investment (ROI) and return on equity (ROE).

In 2007 the EBIDTA/R indicators are positive. The firms that supply port services and general services have the highest values. The ROS indicator, net of amortization, generally presents much lower values with a negative value in the case of rail transport. The group of indicators that have the returns in the numerator (ROA, ROI and ROE) presents high values in the case of the firms offering services to goods, or general services. Road transport has a negative 
Table 6: Balance sheet indicators (2007)

\begin{tabular}{|c|c|c|c|c|c|c|}
\hline Sector & No of firms & $E B I D T A / R$ & ROS & $R O A$ & $R O I$ & $R O E$ \\
\hline Agents & 26 & 2.09 & 1.95 & 5.54 & 5.59 & 16.07 \\
\hline Forwarders & 50 & 1.24 & 3.01 & 5.41 & 2.97 & 4.31 \\
\hline Shipping companies & 2 & 2.60 & 1.30 & 2.70 & 1.90 & 1.70 \\
\hline Terminal operators & 13 & 6.13 & 4.29 & 5.00 & 3.93 & 3.08 \\
\hline Road transport & 15 & 2.35 & 1.26 & 2.42 & -0.69 & 0.62 \\
\hline Railways & 3 & 5.96 & -7.33 & -1.54 & 1.28 & -1.10 \\
\hline Port services & 4 & 15.68 & 6.59 & 4.84 & 4.35 & 5.76 \\
\hline General services & 23 & 16.41 & 9.56 & 11.36 & 12.70 & 15.17 \\
\hline Services to ships & 8 & 2.08 & 1.43 & 4.32 & 1.50 & 8.25 \\
\hline Labour pools & 12 & 5.07 & 2.92 & 5.65 & 5.58 & 31.83 \\
\hline Services to goods & 4 & 10.07 & 7.51 & 14.87 & 16.62 & 36.03 \\
\hline Manufacturing & 44 & 5.09 & 3.84 & 2.96 & 1.19 & 6.85 \\
\hline Construction & 20 & 10.51 & 6.96 & 4.96 & 5.11 & -11.01 \\
\hline Commerce & 21 & 1.14 & -1.08 & 1.31 & -2.42 & -4.07 \\
\hline Services & 8 & 19.29 & 9.53 & 11.47 & 15.22 & 25.35 \\
\hline
\end{tabular}

ROI, rail transport a negative ROA and ROE, and the construction sector a negative ROE. The firms that supply services to goods, as well as the labour pools, being characterized by low levels of equity, have high ROE values. Overall, the firms' transport-related activities in the FVG port system have in 2007 an average ROE equal to 11.07; a relatively good profitability, compared with the 6.85 value of the firms that perform manufacturing activities within the same area.

\section{The Role of Port System in the Economy}

In order to evaluate how the FVG port system interacts with the remaining sectors of the economy, a bi-regional I-O model has been built. Since such a model was not available, a five-sector bi-regional model, for the regions of FVG and OIRs, was initially constructed (for the details of the methodology used cf. Danielis, 2011, p. 93). These five sectors are: primary and secondary manufacturing, transport, commerce, construction and services. Then, the FVG transport sector has been disaggregated into 12 port sectors plus the remaining transport sector. The final result is a bi-regional (FVG and OIRs) I-O model with $12+5$ FVG sectors and five OIRs sectors. Such model can be used for the structural, multiplier and impact analysis (Miller and Blair, 1985). The model allows us to coherently compare the FVG port system with the other sectors, estimate their backward and forward linkages and perform impact analysis, that is, how a change in the FVG port system affects the economy and vice versa.

\footnotetext{
(C) 2013 Macmillan Publishers Ltd. 1479-2931 Maritime Economics \& Logistics Vol. 15, 2, 222-255 237
} 
Focusing on the aggregate data of the I-O table, the direct economic importance of the FVG port system for the FVG region is the following. The FVG port system generates 3 per cent of total regional output (1974 million $€$, hereafter $M €$ ), 1.3 per cent of total regional value added (424 M€) and 3.9 per cent ( $147 \mathrm{M} €$ ) of the regional net tax revenue. Its contribution to trade is 9.2 per cent of exports and 8.5 per cent of imports. As mentioned, the direct employment is equal to $5353-8243$ jobs, that is $0.9-1.4$ per cent of the total regional employment. The total (direct and indirect) economic importance though, estimated as explained in the next sections, is equal in terms of revenue to $1032-3055 \mathrm{M} €$, and in terms of employment to 11443 jobs, depending on the assumption made.

The I-O model allows us to estimate how output, employment and income change due to a change in final demand (that is, private or public consumption, investment, export or change in inventory). Impact analysis depends on the type of model used as discussed in Miller and Blair (1985). The bi-regional (FVG-OIRs) I-O model, open to foreign trade (so that part of the multiplier effect is produced abroad and is not accounted for in the model), but closed with respect to income (so that the income obtained is assumed to be spent according to the current expenditure pattern; that is, Type 2 income multiplier), produces the multipliers reported in Table 7.

A unit variation in the final demand for the average FVG port system has an output multiplier effect on the national economy equal to 3.15 (column 1), a reasonably high value, with some variability among sectors (road transport and logistics being the highest, and port services the lowest). However, the effect on the FVG economy is limited to an average of 1.34 output effect (column 2)

Table 7: Output and income multipliers

\begin{tabular}{lcccc}
\hline Sector & $\begin{array}{c}\text { National output } \\
\text { multiplier }\end{array}$ & $\begin{array}{c}\text { FVG output } \\
\text { multiplier }\end{array}$ & $\begin{array}{c}\text { Induced output } \\
\text { multiplier }\end{array}$ & $\begin{array}{c}\text { Direct + indirect } \\
\text { income variation }\end{array}$ \\
\hline Agents & 2.71 & 1.12 & 1.22 & 0.98 \\
Forwarders & 3.34 & 1.14 & 1.52 & 1.23 \\
Shipping companies & 3.07 & 1.07 & 1.54 & 1.25 \\
Terminal operators & 3.68 & 1.90 & 1.58 & 1.28 \\
Public agencies & 2.94 & 1.40 & 1.46 & 1.18 \\
Road transport & 4.14 & 1.16 & 1.92 & 1.55 \\
Railways & 3.05 & 1.07 & 1.52 & 1.23 \\
Port services & 2.30 & 1.27 & 0.98 & 0.79 \\
General services & 2.91 & 1.50 & 1.29 & 1.05 \\
Services to ships & 3.41 & 1.21 & 1.54 & 1.24 \\
Labour pools & 3.09 & 1.55 & 1.51 & 1.22 \\
Services to goods & 3.19 & 1.67 & 1.42 & 1.15 \\
Average FVG port system & 3.15 & 1.34 & 1.46 & 1.18 \\
\hline
\end{tabular}


(terminal operators having the highest value and shipping companies the lowest). The induced component of the total multiplier (column 3 ) is equal, on average, to 1.46 , that is, almost half of the total effect (3.15). This is due to the income generated, the remaining to the production interdependences. The fourth column reports on the income effect of a unit variation in port service final demand. On average, when the final demand increases by 1 , income increases nationally by 1.18 .

It has been possible, within the I-O framework, to also estimate employment multipliers: Thus, an $M €$ increase in the final demand for the average FVG port system will push employment up by 7.13 labour units (for details, cf. Danielis, 2011, p. 114).

\section{A methodology to estimate the technological self-sufficiency of a port system}

The I-O table presented in Figure 2 can be written in compact form:

$$
\left[\begin{array}{c}
x^{P} \\
x^{R} \\
x^{I}
\end{array}\right]=\left[\begin{array}{ccc}
X^{P P} & X^{P R} & X^{P I} \\
X^{R P} & X^{R R} & X^{R I} \\
X^{I P} & X^{I R} & X^{I I}
\end{array}\right]+\left[\begin{array}{c}
y^{P} \\
y^{R} \\
y^{I}
\end{array}\right]
$$

where $x^{P}$ is the output vector of the 12 FVG port sectors, $x^{R}$ is the output vector of the remaining five FVG industrial sectors and $x^{I}$ is the output vector of the five sectors located in the OIRs. The final demand vector $y$ and the flow matrices $X$ are similarly defined. For instance, the rectangular matrix $X^{I P}$ contains the inputs bought by the 12 FVG port sectors from the OIRs. The accounting scheme is made operational and transformed in a model via the Leontief assumption $A=X \hat{x}^{-1}$, that allows us to rewrite (1) as:

$$
\left[\begin{array}{l}
x^{P} \\
x^{R} \\
x^{I}
\end{array}\right]=\left[\begin{array}{lll}
A^{P P} & A^{P R} & A^{P I} \\
A^{R P} & A^{R R} & A^{R I} \\
A^{I P} & A^{I R} & A^{I I}
\end{array}\right]\left[\begin{array}{l}
x^{P} \\
x^{R} \\
x^{I}
\end{array}\right]+\left[\begin{array}{l}
y^{P} \\
y^{R} \\
y^{I}
\end{array}\right]
$$

This can be solved, thanks to the Leontief assumption, as:

$$
\left[\begin{array}{c}
x^{P} \\
x^{R} \\
x^{I}
\end{array}\right]=\left[\begin{array}{ccc}
I-A^{P P} & -A^{P R} & -A^{P I} \\
-A^{R P} & I-A^{R R} & -A^{R I} \\
-A^{I P} & -A^{I R} & I-A^{I I}
\end{array}\right]^{-1}\left[\begin{array}{c}
y^{P} \\
y^{R} \\
y^{I}
\end{array}\right]=\left[\begin{array}{ccc}
B^{P P} & B^{P R} & B^{P I} \\
B^{R P} & B^{R R} & B^{R I} \\
B^{I P} & B^{I R} & B^{I I}
\end{array}\right]\left[\begin{array}{c}
y^{P} \\
y^{R} \\
y^{I}
\end{array}\right]
$$

where the identity matrix $I$ has the needed dimension. Matrix $B$, here partitioned into nine sub-matrices, contains the multipliers of the port production, of 


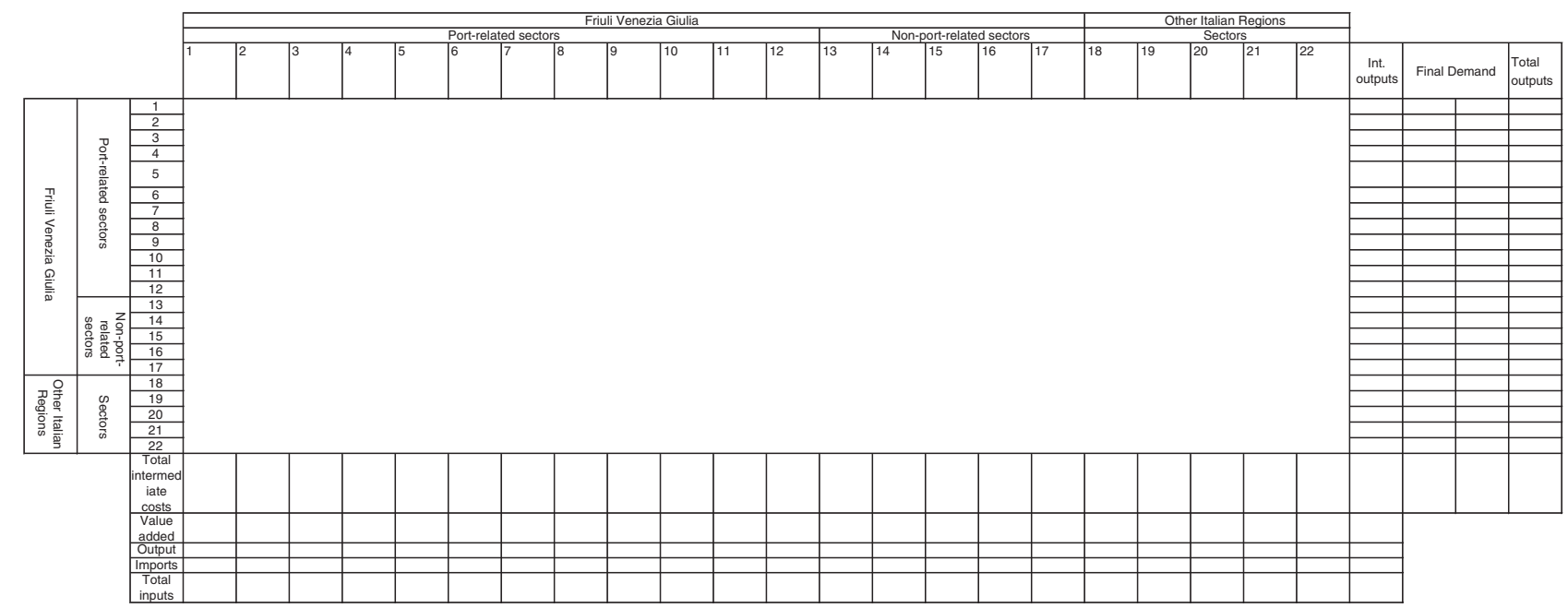

Figure 2: Graphical illustration of the bi-regional (FVG-0ther Italian Regions), 22-sector input-output table. The table with the actual data is available in Danielis (2011). 
the other FVG industrial sectors and of the OIRs' sectors activated by a change of the final demand.

Since we aim at analysing how and how strongly the port sectors are linked with the remaining industries, it is convenient to decompose the multiplier matrices. In order to simplify the analysis it is useful to consider a bi-partitioned model made up of the port sectors and of the non-port sectors, regardless whether localized in the FVG or in the OIRs. This simple I-O model has a solution as follows:

$$
\left[\begin{array}{l}
x^{P} \\
x^{N}
\end{array}\right]=\left[\begin{array}{cc}
I-A^{P P} & -A^{P N} \\
-A^{N P} & I-A^{N N}
\end{array}\right]^{-1}\left[\begin{array}{l}
y^{P} \\
y^{N}
\end{array}\right]=\left[\begin{array}{ll}
B^{P P} & B^{P N} \\
B^{N P} & B^{N N}
\end{array}\right]\left[\begin{array}{l}
y^{P} \\
y^{N}
\end{array}\right]
$$

where variables have the standard meaning. The inverse can be written via the Aitken block-diagonalization as:

$$
\begin{aligned}
{\left[\begin{array}{cc}
I-A^{P P} & -A^{P N} \\
-A^{N P} & I-A^{N N}
\end{array}\right]=} & {\left[\begin{array}{cc}
I & 0 \\
-A^{N P}\left(1-A^{P P}\right)^{-I} & I
\end{array}\right]\left[\begin{array}{cc}
I-A^{P P} & 0 \\
0 & S
\end{array}\right] } \\
& \times\left[\begin{array}{cc}
I & -\left(I-A^{P P}\right)^{-1} A^{P N} \\
0 & I
\end{array}\right]
\end{aligned}
$$

where $S=I-A^{N N}-A^{N P}\left(I-A^{P P}\right)^{-1} A^{P N}$. The matrix $S$ is also known as Schur's complement. It can be proved that equation (4) has a solution only if $I-A^{P P}$ and the Schur's complement are not singular and, hence, can be inverted. In such a case, the inverse can be written as:

$$
\left[\begin{array}{ll}
B^{P P} & B^{P N} \\
B^{N P} & B^{N N}
\end{array}\right]=\left[\begin{array}{cc}
{\left[I+\left(I-A^{P P}\right)^{-1} A^{P N} S^{-1} A^{N P}\right]\left(I-A^{P P}\right)^{-1}} & \left(I-A^{P P}\right)^{-1} A^{P N} S^{-1} \\
S^{-1} A^{N P}\left(I-A^{P P}\right)^{-1} & S^{-1}
\end{array}\right]
$$

The model can be solved with a different ordering of the matrix:

$$
\left[\begin{array}{ll}
B^{P P} & B^{P N} \\
B^{N P} & B^{N N}
\end{array}\right]=\left[\begin{array}{cc}
H & H A^{P N}\left(I-A^{N N}\right)^{-1} \\
\left(I-A^{N N}\right)^{-1} A^{N P} H & {\left[I+\left(I-A^{N N}\right)^{-1} A^{N P} H A^{P N}\right]\left(I-A^{N N}\right)^{-1}}
\end{array}\right]
$$

Therefore, the multiplier matrix of the port production with respect to the port demand can be expressed as either as:

$$
H=B^{P P}=\left[I-A^{P P}-A^{P N}\left(I-A^{N N}\right)^{-1} A^{N P}\right]^{-1}
$$


or

$$
B^{P P}=\left[I+\left(I-A^{P P}\right)^{-1} A^{P N} S^{-1} A^{N P}\right]\left(I-A^{P P}\right)^{-1}
$$

The interpretation of equation (8) is immediate when we recall that the inverse of a non-singular matrix can be expressed by the Neumann's series, so that $(I-A)^{-1}=I+A+A^{2}+A^{3}+\cdots+A^{n}+\cdots$. Therefore, the port output multipliers are due to the direct technical coefficients of the port's sectors $\left(A^{P P}\right)$ and by the forward and feedback effects. In fact, an output increase in a port sector stimulates production in the other sectors. Such a forward effect is captured in the matrix $A^{N P}$. We know that a demand increase in non-port goods leads to an increase in their production that, cycle by cycle, is captured by the inverse matrix $\left(I-A^{N N}\right)^{-1}$. Moreover, the increased production leads to a further increase in the demand for port services, determined by the input coefficient matrix $A^{P N}$. This explains why the propagation effect outside the port is null when the matrices $A^{P N}$ or $A^{N P}$ are made up of zero values. If the $A^{P N}$ matrix is null, an increase in non-port production does not stimulate port production. Conversely, if the $A^{N P}$ matrix is made up of zero elements, the port production is self-sufficient and does not generate effects on the remaining sectors of the economy.

Equation (8) confirms the importance of these links to calculate the forward effect. Actually, the port production activated by its own demand in an 'autarchic' regime is given by $\left(I-A^{P P}\right)^{-1}$, which is the driving force in equation (9). But this causes a spill-over effect on the rest of the economy that is greater the larger the matrix $A^{N P}$ is. Such increase in production activates, in turn, the remaining sectors, as expressed by Schur's matrix, $S$, whose inverse captures the total variation. The final effect is an increase in port service demand, unless the $A^{P N}$ matrix is zero. The demand increase, in turn, increases the port output according to its integration measure captured by $\left(I-A^{P P}\right)^{-1}$.

In conclusion, the forward and backward effects are lower, the lower the coefficients of the activation matrices $A^{P N}$ and $A^{N P}$. In the literature, various metrics exist with regard to matrices with non-negative elements, such as the spectral norm or the Frobenius norm, but there is no immediate interpretation of their value (Salce, 1993). Since it is convenient to analyse the importance of these matrices for the port system, a first exercise consists in observing the total multipliers matrix, $B^{P P}$, that refers only to intra-port activation. One can estimate the share attributable to the inverse matrix $\left(I-A^{P P}\right)^{-1}$.

The application of this methodology of matrix decomposition to the TIS bi-regional FVG-OIRs 2007 leads to the result illustrated in Table 8.

The $i j$ values presented in Table 8 indicate the share of internal activation (ith row) deriving from an increase in the sectorial final demand (jth column). 
Table 8: Share of internal activation in total production in the FVG_PS

\begin{tabular}{|c|c|c|c|c|c|c|c|c|c|c|c|c|c|c|}
\hline & & 1 & 2 & 3 & 4 & 5 & 6 & 7 & 8 & 9 & 10 & 11 & 12 & $\begin{array}{c}\text { Average } \\
\text { row }\end{array}$ \\
\hline 1 & Agents & 100 & 99 & 100 & 99 & 76 & 97 & 58 & 98 & 97 & 72 & 93 & 3 & 82.7 \\
\hline 2 & Forwarders & 99 & 100 & 37 & 100 & 70 & 97 & 95 & 69 & 68 & 99 & 81 & 2 & 76.4 \\
\hline 3 & Shipping companies & 95 & 99 & 100 & 100 & 98 & 59 & 99 & 100 & 100 & 98 & 100 & 29 & 89.8 \\
\hline 4 & Terminal operators & 100 & 100 & 64 & 100 & 6 & 60 & 85 & 3 & 3 & 42 & 21 & 0 & 48.7 \\
\hline 5 & Public agencies & 100 & 100 & 100 & 100 & 100 & 93 & 99 & 100 & 100 & 100 & 99 & 100 & 99.3 \\
\hline 6 & Road transport & 98 & 100 & 94 & 100 & 100 & 100 & 93 & 85 & 86 & 99 & 100 & 70 & 93.8 \\
\hline 7 & Railways & 77 & 96 & 52 & 99 & 100 & 94 & 100 & 80 & 79 & 59 & 100 & 70 & 83.8 \\
\hline 8 & Port services & 98 & 94 & 32 & 100 & 98 & 13 & 70 & 100 & 99 & 100 & 95 & 41 & 78.3 \\
\hline 9 & General services & 100 & 99 & 87 & 100 & 100 & 42 & 71 & 100 & 100 & 91 & 100 & 76 & 88.8 \\
\hline 10 & Services to ships & 100 & 99 & 95 & 100 & 99 & 47 & 73 & 100 & 100 & 100 & 99 & 58 & 89.2 \\
\hline 11 & Labour poops & 99 & 100 & 32 & 100 & 20 & 65 & 86 & 17 & 17 & 91 & 100 & 0 & 60.6 \\
\hline 12 & Services to goods & 87 & 100 & 5 & 99 & 1 & 18 & 22 & 1 & 1 & 40 & 100 & 100 & 47.8 \\
\hline & Average & 96.1 & 98.8 & 66.5 & 99.8 & 72.3 & 65.4 & 79.3 & 71.1 & 70.8 & 82.6 & 90.7 & 45.8 & 78.3 \\
\hline
\end{tabular}


For instance, the value 95, third row and first column, shows that an increase in maritime and customs agents final demand induces a change in the production of shipping companies, 95 per cent of which remains in the FVG_PS whereas the remaining 5 per cent has an effect outside the FVG_PS. The high values of the first column, hence, indicate that final demand by the maritime and customs agents activates production almost exclusively within the FVG_PS (96.1 per cent). However, if we consider the services-to-goods sector the picture is quite different, with a smaller value (45.8). This means that the multiplying process of the final demand for services to goods activates production to an important extent outside the FVG_PS. It can also be noted that some sectors, for instance row 5, public agencies, have an activation effect across sectors outside the FVG_PS close to zero (99.8).

To summarize, the table allows us to conclude that the FVG_PS has a quite high level of self-sufficiency, on average equal to 78.3 per cent. That is, the final demand for port services activates production 75 per cent of which taking place within the FVG_PS itself. The positive interpretation of this result is that, at least from a technological point of view, the FVG_PS is a 'cluster'4 The negative aspect is that the FVG_PS has weak relationships with the remaining economic sectors, a result already found by Doi et al (2001) as illustrated above.

\section{The economic importance of the port system}

In many empirical studies, the estimate of indirect employment is presented but it is not clearly explained how it is obtained. Generally, there is a reference to a multiplier, quoted from the literature, which transforms the direct employment estimate into an estimate of indirect employment. Consequently, such multiplier is somewhat 'ad hoc', external to the analytical framework used.

In other applications, the indirect employment is said to be derived from inputs bought by the port sector from other sectors. Employment $\backslash$ output ratios, derived from the national I-O tables, are then used to come up with an estimate of indirect employment. In such a case, the entire backward $\backslash$ forward linkage structure is lost. Coppens (2005) is, to our knowledge, the only paper that tries to define in a sound approach what is meant by 'indirect effect'. He defines it on the basis of the I-O model, but fails to account for some recent theoretical developments.

In this section we present and apply a methodology that provides a coherent and explicit framework to estimate the total output and employment importance of a port.

The analysis presented in the first subsection is useful since it provides an estimate of the level of integration of the port system within the economy. However, this is only a starting point because it does not consider the absolute 
levels of final demand. In other words, the values provided are only potential, because if final demand is small or null, the induced production is small or null too, notwithstanding the indirect effect. Hence, a methodology that captures both the actual value of the final demand and the indirect effect is needed.

A useful approach is due to Paelinck et al (1965) and Strassert (1968) who developed a methodology that can quantify the output loss if a given sector would not exist. The initial proposal is quite simple. It consists of deleting a row and a column of the Leontief matrix and the corresponding final demand. In doing so, one assumes that the production is entirely substituted by imports. The more important the sector is, the larger the total output loss. Similarly, one can proceed with deleting a group of homogenous sectors.

However, borrowing from the backward and forward linkages literature (Rasmussen, 1956; Chenery and Watanabe, 1958; Augustinovics, 1970; Jones, 1976; Schultz, 1976; Harrigan and McGilvrey, 1988), it resulted that deleting a whole sector makes little sense. It is more useful to cancel out some or all of the links of the sector under examination, since it continues to exist and offer its goods and services, but with a different technology that does not use some or all of the intermediate goods, or supplies only final demand. In so doing, it is possible to identify the various propagation channels and the different pull and push factors, without using the Ghosh supply approach. ${ }^{5}$

Formally, one should estimate how much production is lost when $A^{P P}=A^{N P}=A^{P N}=0$ and the Leontief inverse matrix reduces to:

$$
\bar{B}=\left[\begin{array}{cc}
I & 0 \\
0 & \left(I-A^{N N}\right)^{-1}
\end{array}\right]
$$

so that the difference between the realized and this 'theoretically possible' output is given by:

$$
\left\lfloor\begin{array}{c}
\Delta x_{1}^{P} \\
\Delta x_{1}^{N}
\end{array}\right\rfloor=\left[\begin{array}{cc}
H-I & H A^{P N}\left(I-A^{N N}\right)^{-1} \\
\left(I-A^{N N}\right)^{-1} A^{N P} H & \left(I-A^{N N}\right)^{-1} A^{N P} H A^{P N}\left(1-A^{N N}\right)^{-1}
\end{array}\right]\left[\begin{array}{l}
y^{P} \\
y^{N}
\end{array}\right]
$$

Following Miller and Lahr (2001), it is possible to propose some alternatives. The simplest and most used is the 'complete specialization' one, in the sense that the port sector keeps on utilizing the intermediate goods, but only those produced within the cluster. This is to assume $A^{N P}=A^{P N}=0$, so the Leontief inverse matrix becomes:

$$
\hat{B}=\left[\begin{array}{cc}
\left(I-A^{P P}\right)^{-1} & 0 \\
0 & \left(I-A^{N N}\right)^{-1}
\end{array}\right]
$$


Using equation (9), the difference between the realized and the new 'theoretically possible' output is given by:

$$
\begin{aligned}
\left\lfloor\begin{array}{c}
\Delta x_{2}^{P} \\
\Delta x_{2}^{N}
\end{array}\right]= & {\left[\begin{array}{cc}
\left(I-A^{P P}\right)^{-1} A^{P N} S^{-1} A^{N P}\left(1-A^{P P}\right)^{-1} & H A^{P N}\left(I-A^{N N}\right)^{-1} \\
\left(I-A^{N N}\right)^{-1} A^{N P} H & \left(I-A^{N N}\right)^{-1} A^{N P} H A^{P N}\left(1-A^{N N}\right)^{-1}
\end{array}\right] } \\
& \times\left[\begin{array}{c}
y^{P} \\
y^{N}
\end{array}\right]
\end{aligned}
$$

Cella (1984) proposed to decompose the total variation into two components, based on the origin of the final demand. Specifically, he defines a backward linkage as one that depends on the sector (or industry) whose linkages have been cancelled out, in our case the port sector. Hence, the total value of the backward linkage is the sum of the decreased output, wherever produced, due to the port final demand:

$$
B L^{P}=i^{\prime}\left(I-A^{P P}\right)^{-1} A^{P N} S^{-1} A^{N P}\left(I-A^{P P}\right)^{-1} y^{P}+i^{\prime}\left(I-A^{N N}\right)^{-1} A^{N P} H y^{P}
$$

where $i$ is a unit vector that allows the summation of all elements in a conformable vector. One could immediately see that this indicator is equal to zero only if the input matrix of the port sector service from the OIRs is zero and feedback effects do not exist. Similarly, the forward linkage can be defined as:

$$
F L^{P}=i^{\prime} H A^{P N}\left(I-A^{N N}\right)^{-1} y^{N}+i^{\prime}\left(I-A^{N N}\right)^{-1} A^{N P} H A^{P N}\left(I-A^{N N}\right)^{-1} y^{N}
$$

and it is equal to zero only if the port sector does not sell its services to the remaining sectors.

Miller and Lahr (2001) propose alternative elimination strategies, consisting of deleting one or more sub-matrices described in equation (4). For instance, one can eliminate only one of the two exchange matrices, that is $A^{N P}$ o $A^{P N}$.

Let us imagine, in our specific case, the closure of the FVG_PS. The direct economic loss in terms of revenue would be 1975 million euro. This figure indicates the direct economic importance of the FVG_PS. But it does not include the indirect effect due to the forward and backward linkages.

On the substitution of the port service, one can make the following assumption:

(a) Port services are imported from abroad (for example, from the port of Koper, Slovenia, located at a distance of one hour south of Trieste).

(b) Port services are substituted by other transport services (for example, road services) produced in the FVG region with the current technology. 
Table 9: Change in production if the FVG_PS is closed down (M€)

\begin{tabular}{|c|c|c|c|c|}
\hline Sectors & $\begin{array}{c}\text { Current output } \\
\text { with FVG_PS }\end{array}$ & $\begin{array}{c}\text { Estimated output } \\
\text { if port services are } \\
\text { imported from } \\
\text { abroad }\end{array}$ & $\begin{array}{l}\text { Estimated output } \\
\text { if port services are } \\
\text { substituted from } \\
\text { other non-port } \\
\text { transport services } \\
\text { produced in FVG }\end{array}$ & $\begin{array}{c}\text { Estimated output } \\
\text { if port services are } \\
\text { substituted from } \\
\text { other port services } \\
\text { produced in OIRs }\end{array}$ \\
\hline Transp\&Comm FVG & 4286 & 4268 & 5352 & 4268 \\
\hline Manuf FVG & 19888 & 19862 & 19915 & 19863 \\
\hline Constr FVG & 5476 & 5471 & 5516 & 5471 \\
\hline Comm FVG & 8629 & 8612 & 8688 & 8612 \\
\hline Serv FVG & 26059 & 26012 & 26207 & 26014 \\
\hline Transp\&Comm 0IRs & 280546 & 280089 & 280117 & 281340 \\
\hline Manuf OIRs & 955101 & 954922 & 955001 & 955149 \\
\hline Constr OIRs & 277712 & 277672 & 277725 & 277758 \\
\hline Comm OIRs & 401033 & 400937 & 400995 & 401085 \\
\hline Serv 0IRs & 1161959 & 1161763 & 1161885 & 1162071 \\
\hline Total & 3140689 & 3139608 & 3141401 & 3141631 \\
\hline FVG_PS & 1975 & 0 & 0 & 0 \\
\hline Global total & 3142664 & 3139608 & 3141401 & 3141631 \\
\hline Total loss & - & 3056 & 1263 & 1033 \\
\hline
\end{tabular}

Obviously, this is a strong assumption since port services cannot be easily substituted by other technologies.

(c) Port services are substituted by port services produced in OIRs with the current technology (for example, the port of Venice, located 2 hours east of Trieste).

The impact on output and the total loss for the entire national economy (FVG + OIRs) are summarized in Table 9.

Under assumption (a), that is, closure of the FVG_PS and substitution with imports from abroad, the output loss would be equal to $3056 \mathrm{M€}$. FVG and OIRs sectors would experience a decrease in production due to the indirect effects. In particular, the largest output loss would be experienced in the OIRs (in the transport and communications sector and in the service sector) because the FVG_PS buy considerable inputs from those sectors.

Assumption (b), substitution with other transport services (for example, road services) produced in the FVG region with the current technology, would entail obviously a large output in the FVG transport and communications sector. Overall, however, a loss of $1263 \mathrm{M€}$ would be experienced because of the technological and forward and backward linkage shift. As mentioned, this assumption is unrealistic. 
It is probably more realistic to assume substitution by port services produced in OIRs with the current technology, as in the third assumption. This would also entail a total loss of $1033 \mathrm{M} €$ even though the OIRs transport and communications sector would experience a production increase.

Consequently, depending on the substitution assumption, the economic importance of the FVG_PS can be estimated between 1032 and $3055 \mathrm{M} €$.

Similar estimates can be made with reference to the impact on employment, hence capturing the direct and indirect employment content of the FVG_PS (Danielis, 2011, Table 63). The largest value obtained is 11443 jobs. Hence, the indirect employment lies between $6090 \quad(=11443-5353)$ and 3200 ( $=11443-8243$ ), depending on how direct employment is defined.

Furthermore, one can assume, instead of a total closure of the FVG_PS, a partial closure so that:

1. The FVG_PS operates but it imports all goods and services from abroad, without producing them locally, so that only the primary factors (capital and labour) generate income (Assumption 1, only VA).

2. The FVG_PS operates but it imports all goods and services from abroad and it does not sell nor acquire its services neither to/from the FVG nor to/from the OIRs (Assumption 2, $A^{N P}=A^{P N}=0$ ).

3. The FVG_PS operates but it imports all goods and services from abroad and not from the FVG or OIRs, but it sells its services to the FVG only (Assumption 3, $A^{N P}=0$ ).

4. The FVG_PS operates, it buys goods and services from either the FVG or OIRs but it does not sell them to neither (Assumption 4, $A^{P N}=0$ ).

The impact on port production is summarized in Table 10, that presents in the first column the current production and in the last row the total loss for the national economy.

Under assumption (1) the loss for the FVG_PS is equal to $996 \mathrm{M} €$, whereas the total loss for the national economy would be equal to $2077 \mathrm{M€}$. Under assumption (2), that is, no trade between the FVG_PS and the nonport sectors, the loss for the FVG_PS is equal to $883 \mathrm{M} €$ (lower than the previous case because the port still operates) and the total loss for the national economy is equal to $1963 \mathrm{M} €$. The loss for the FVG_PS is almost null under assumption (3) because it operates and it imports its inputs from abroad while it sells to the remaining sectors. Yet, the total loss for the national economy would be equal to $1081 \mathrm{M} €$. Under assumption (4) the loss of the FVG_PS is again equal to $883 \mathrm{M} €$ because the FVG_PS does not sell its services to the non-port sectors and the total loss is $1426 \mathrm{M€}$. Hence, the total losses range between 2077 and $1081 \mathrm{M€}$. 
Table 10: Impact on FVG_PS production under alternative assumptions (M€)

\begin{tabular}{lrrrrr}
\hline & Current & $\begin{array}{c}\text { Assumption } 1 \\
\text { VA only }\end{array}$ & $\begin{array}{c}\text { Assumption } 2 \\
A^{N P}=A^{P N}=0\end{array}$ & $\begin{array}{c}\text { Assumption } 3 \\
A^{N P}=0\end{array}$ & $\begin{array}{c}\text { Assumption } 4 \\
A^{P N}=0\end{array}$ \\
\hline Agents & 59 & 40 & 42 & 59 & 42 \\
Forwarders & 289 & 68 & 71 & 289 & 71 \\
Shipping companies & 692 & 593 & 606 & 692 & 606 \\
Terminal operators & 211 & 150 & 153 & 211 & 153 \\
Public agencies & 73 & 1 & 47 & 73 & 47 \\
Road transport & 188 & 43 & 51 & 188 & 51 \\
Railways & 290 & 53 & 55 & 290 & 55 \\
Port services & 27 & 14 & 18 & 27 & 18 \\
General services & 53 & 4 & 11 & 53 & 11 \\
Services to ships & 48 & 8 & 13 & 48 & 13 \\
Labour pools & 40 & 3 & 23 & 40 & 23 \\
Services to goods & 4 & 2 & 2 & 4 & 2 \\
Total & 1975 & 978 & 1091 & 1974 & 1091 \\
Output loss in FVG_PS & - & 996 & 883 & 0.7 & 883 \\
Total loss for the whole economy & - & 2077 & 1963 & 1081 & 1426 \\
\hline
\end{tabular}

It can also be observed that, under assumption (2), 72.6 per cent of the loss is due to the forward linkage and 27.3 per cent to the backward one.

Similar impacts have been estimated for employment (Danielis, 2011, pp. 105 and 107).

In summary, the output directly attributable to the FVG_PS is equal to 1975 $M €$. If the FVG_PS is hypothetically closed down, the total loss for the national economy would be equal to (Table 9):

1. $3056 \mathrm{M€}$ if port services are imported from abroad;

2. $1263 \mathrm{M} €$ if port services are substituted by other transport services (for example, road services) produced in the FVG region with the current technology;

3. $1033 M €$ if port services are substituted by port services produced in OIRs with the current technology.

Note that in cases (2) and (3), the total loss for the national economy is lower than the direct output loss for the FVG region. This happens because the backward and forward linkages of the port-related sectors are weaker than those of the other FVG or OIRs transport sectors.

Under the less drastic assumption of partial closure of the FVG_PS, the total loss for the national economy would be equal to (Table 10):

1. 2077 M€ if the FVG_PS operates but it imports all goods and services from abroad, without producing them locally, so that only the primary factors (capital and labour) generate income; 
2. 1963 M€ if the FVG_PS operates but it imports all goods and services from abroad and it does not sell nor acquire its services neither to/from the FVG nor to/from the OIRs;

3. $1081 M €$ if the FVG_PS operates but it imports all goods and services from abroad and not from the FVG or OIRs, but it sells its services to the FVG only;

4. $1426 M €$ if the FVG_PS operates, it buys goods and services from the FVG or OIRs but it does not sell them neither to the FVG nor to the OIRs.

Hence, total (direct + indirect) importance of the FVG_PS varies between $1.033 \mathrm{M} €$ and $3.056 \mathrm{M} €$, depending on which assumption of its substitution and operability is made. Again, it is worth noting that in five cases out of seven, its total importance is less than its direct importance for the same reasons mentioned above.

\section{Conclusions}

The article summarizes the results of a research project aimed at identifying the main economic and industrial characteristics of the FVG port system and at estimating how it is connected with the rest of the economy. Combining a top-down and bottom-up approach, based on interviews and detailed data at firm level, a bi-regional I-O table has been built with a special disaggregation of the port-related sectors of the FVG region. The I-O table provides the basis for the estimation of a bi-regional I-O model. This research project is similar to the one performed for the port of Antwerp (Coppens et al, 2007).

Although many of the criticisms directed to the I-O model, some of which are summarized above, should be acknowledged, a well-known advantage of this approach is that it allows one to estimate both the direct and indirect (employment, revenue, value added, income) impacts of a change in the final demand, in a framework that is consistent with the national and regional accounts. Furthermore, such impacts can be sectorally and geographically specified.

With regard to the identification of the industrial characteristics, the article concludes that the FVG_PS: (a) plays a relevant macroeconomic role in the region; (b) is characterized by a high degree of openness from an economic, commercial and industrial point of view; (c) is part of a larger territorial system.

In the project report comparisons are also made (not presented here) between the current FVG port system and the port of Trieste in year 1900 (Babudieri, 1965) with regard to the number of people directly and indirectly employed nowadays with the port of Venice and the Belgian ports (Danielis, 2011, p. 125). Another relevant finding is that the value added per square-km is much higher in the FVG_SP than in most Belgian ports. 
With regard to the question of how is the FVG port system connected with the rest of the economy, the article not only estimates the relevant multipliers at a 12 port-related sector disaggregation level, but it also proposes two methodologies to estimate, coherently with the I-O modelling framework: (a) the level of self-sufficiency of the port system and (b) its degree of substitutability, that is, what would happen if the FVG port system closes, completely or partially, depending on the assumption made on where the port services are alternatively procured. It is found that the FVG port system has a 78.3 per cent self-sufficiently level and an economic importance ranging between 1.033 M€ and $3.056 \mathrm{M€}$.

Although both methodologies suffer, of course, from the general limitations of the I-O approach, they provide a coherent and explicit methods to evaluate what role does a port, or a port system, play within an economic system.

\section{Acknowledgement}

This research has been made possible by a grant of 60000 euro from the Commissario del Governo, Fondo Trieste. It started in June 2009 and ended in October 2011. The research group was led by Romeo Danielis and included Daniele Andreozzi, Giacomo Borruso, Massimo Gardina, Tullio Gregori, Alessandro Kostoris, Jerome Massiani, Adriana Monte, Loredana Panariti, Paolo Rosato, Lucia Rotaris and Vittorio Torbianelli. Luca Buzzulini, Fabio Franceschinel, Palo Frisenna and Alessia Piccolo collected the data via direct or telephone interviews. Special thanks are due to the Port Authority of Trieste and to Francesco Parisi Spa for the technical support.

\section{Notes}

1 'Port impact studies' or the 'economic importance of a port' are alternative definitions of studies aimed at estimating what is the economic value of a port. We choose to use the wider term of 'economic role' since it better conveys the notion that a port interacts geographically, industrially and economically with the other economic and leisure activities.

2 An 'emporion' denotes in the Mediterranean countries a place which the traders of one nation had reserved to their business interests within the territory of another nation.

3 They group the methodologies used to assess port impact differently. They propose the following classification: direct surveys based on interviews and questionnaires or microeconomic data on firms (Coppens et al, 2007); I-O models constructed in order to obtain intersectoral multipliers (Warf and Cox, 1989; Castro and Coto-Millan, 1998; CENSIS - Federazione del mare, 1998); and models based on productive specialization that use a mix of tools typical of applied economics, such as comparison with a control region (Rietveld, 1994) or analysis of productive specialization (Musso et al, 2000).

(C) 2013 Macmillan Publishers Ltd. 1479-2931 Maritime Economics \& Logistics Vol. 15, 2, 222-255 251 
4 But since, according to De Langen (2003), the organizational, management and promotional aspects are an essential part of the cluster concept, and they are not considered in this research, we used the more conservative concept of port system.

5 The supply drive model developed by Ghosh (1958) and Augustinovics (1970) assumes a fixed allocation of outputs over sectors, that is, stable sale coefficients are estimated dividing sales by total output. This approach has been widely criticized as it yields implausible results.

\section{References}

Acciaro, M. (2008) The role of ports in the development of Mediterranean islands: The case of Sardinia. International Journal of Transport Economics 35(3): 295-323.

Acosta, M., Cerban, M. and Coronado, D. (2010) The port of Tarifa (Spain): Economic impact in 2007 and foresight 2015. Conference proceedings of the International Association of Maritime Economists 2010 Conference. Lisbon.

Augustinovics, M. (1970) Methods of international and intertemporal comparison of structure. In: A.P. Carter and A. Brody (eds.) Contributions to Input-Output analysis. Amsterdam, the Netherlands: North-Holland.

Babudieri, F. (1965) I porti di Trieste e della regione Giulia dal 1815 al 1918. Collana: Archivio economico dell'unificazione italiana. Ser. 1, Vol. 14, fascicolo 2, Roma.

Bichou, K. (2007) Review of port performance approaches and a supply chain framework to port performance benchmarking. In: M. Brooks and K. Culliname (eds.) Research in Transportation Economics. Devolution, Port Governance and Port Performance. London: Elsevier, Vol. 17, pp. 567-598.

Bichou, K. and Gray, R. (2005) A critical review of conventional terminology for classifying seaports. Transportation Research A 39(1): 75-92.

Braun, B.B. (1990) Measuring the influence of public authorities through economic impact analysis: The case of Port Canaveral. Policy Studies Journal 18(4): 1032-1044.

Braun, B.M., Xander, J.A. and White, K.R. (2002) The impact of the cruise industry on a region's economy: A case study of Port Canaveral, Florida. Tourism Economics 8(3): 281-288.

Bryan, J., Munday, M., Pickernell, D. and Roberts, A. (2006) Assessing the economic significance of port activity: Evidence from ABP Operations in industrial South Wales. Maritime Policy and Management 33(4): 371-386.

Bureau of Transport Economics. (2000) Regional Impact of Ports. Report 101, Commonwealth of Australia.

Castillo, J.I., López-Valpuesta, L. and Aracil, M.-J. (2007) Dynamising economic impact studies: The case of the Port of Seville. In: P. Coto-Millan and V. Inglada (eds.) Essays on Transport Economics. Leipzig, Germany: Physica-Verlag.

Castro, J.V. and Coto-Millan, P. (1998) Port economic impact: Methodologies and application to the port of Santander. International Journal of Transport Economics 25(2): 159-179.

Cella, G. (1984) The input-output measurement of interindustry linkages. Oxford Bulletin of Economics and Statistics 46(4): 73-84.

CENSIS - Federazione del mare. (1998) Rapporto sull'economia del mare - L'impatto socioeconomico delle attività di impresa marittima nello sviluppo del paese. Milano, Italy: Franco Angeli.

Chang, S. (1978) In defense of port economic impact studies. Transportation Journal 16(3): 65-85.

Chenery, H. and Watanabe, T. (1958) International comparisons of the structure of production. Econometrica 26(4): 487-521.

Coppens, F. (2005) Indirect Effects - A Formal Definition and Degrees of Dependency as an Alternative to Technical Coefficients. Working paper document no 67 (May), National Bank of Belgium.

252 (C) 2013 Macmillan Publishers Ltd. 1479-2931 Maritime Economics \& Logistics Vol. 15, 2, 222-255 
Coppens, F. et al (2007) Economic Impact of Port Activity: A Disaggregate Analysis. The case of Antwerp. Working paper document no, 110 (February), National Bank of Belgium.

Coto-Millán, P., Mateo-Mantecón, I. and Villaverde Castro, J. (2010a) The economic impact of ports: Its importance for the region and also the Hinterland. In: P. Coto-Millán, M.A. Pesquera and J. Castanedo (eds.) Essays on Port Economics. Contributions to Economics. Heidelberg: PhysicaVerlag.

Coto-Millán, P., Pesquera, M.A. and Castanedo Gatan, J. (eds.) (2010b) A methodological discussion on port economic impact studies and their possible applications to policy design. In: Essays on Port Economics. Contributions to Economics. Heidelberg: Physica-Verlag.

Crompton, J. (1995) Economic impacts analysis of sports facilities and events: Eleven sources of misapplication. Journal of Sport Management 9(1): 14-35.

Crompton, J. (2004) Beyond economic impact: An alternative rationale for the public subsidy of major league sports facilities. Journal of Sport Management 18(1): 40-58.

Crompton, J. (2006) Economic impact studies: Instruments for political shenanigans? Journal of Travel Research 45(1): 67-82.

Danielis, R. (ed.) (2011) Il sistema marittimo-portuale del Friuli Venezia Giulia. Caratteristiche strutturali e interdipendenze settoriali. In: Il sistema marittimo-portuale del Friuli Venezia Giulia. Aspetti economici, statistici e storici. Trieste, Italy: EUT, http://hdl.handle.net/10077/5690.

Davis, H.C. (1983) Regional port impact studies: A critique and suggested methodology. Transportation Journal 23(2): 61-71.

de Langen, P.W. (2003) The performance of seaport clusters. A framework to analyze cluster performance and an application to the seaport clusters of Durban, Rotterdam and the Lower Mississippi. PhD Thesis, Erasmus University Rotterdam.

DeSalvo, J.S. (1994) Measuring the direct impacts of a port. Transportation Journal 33(4): 33-42.

Doi, M., Tiwari, P. and Itoh, H. (2001) A computable general equilibrium analysis of efficiency improvements at Japanese ports. Review of Urban \& Regional Development 13(3): 187-206.

Dooms, M., Haezendonck, E. and Verbeke, A. (2011) Towards a toolkit for port related socioeconomic impacts: A meta-analysis of socio-economic impact studies conducted for seaports. Paper presented at the European Conference on Shipping \& Ports 2011, University of the Aegean, Greece.

EconSearch Pty Ltd. (2001) The Economic Impact of the Port of Esperance, 1999/2000. A report prepared for Esperance Port Authority, Prepared by EconSearch Pty Ltd.

Ferrari, C., Percoco, M. and Tedeschi, A. (2010) Ports and local development: Evidence from Italy. International Journal of Transport Economics 37(1): 9-28.

Francou, B., Carrera-Gómez, G., Coto-Millan, P., Castanedo-Galàn, J. and Pesquera, M.A. (2007) Economic impact study: Application to ports. In: P. Coto-Millan and V. Inglada (eds.) Essays on Transport Economics. Leipzig, Germany: Physica-Verlag, Part III: pp. 147-157.

Ghosh, A. (1958) Input-output approach to an allocative system. Economica 25(1): 58-64.

Gripaios, P. and Gripaios, R. (1995) The impact of a port on its local economy: The case of Plymouth. Maritime Policy \& Management 22(1): 13-24.

Guerrero, J.I.F., Selva, L.M. and Medina, R.P. (2008) Economic impact of western Mediterranean leisure ports. International Journal of Transport Economics 35(2): 251-272.

Haddad, E.A., Hewings, G.J.D., Perobelli, F.S., dos Santos, R.A.C. and Raul, A.C. (2010) Regional effects of port infrastructure: A spatial CGE application to Brazil. International Regional Science Review 33(3): 239-263.

Haezendonck, E., Coeck, C. and Verbeke, A. (2000) The competitive position of seaports: Introduction of the value added concept. International Journal of Maritime Economics 2(2): 69-82.

Hall, P.V. (2004a) We'd have to sink the ships: Impact studies and the 2002 West Coast port lockout. Economic Development Quarterly 18(4): 354-367.

Hall, P.V. (2004b) Mutual specialization, seaports and the geography of automobile imports. Tijdschrift voor Economische en Sociale Geografie 95(2): 135-146. 
Hamilton, G.L., Ramsussen, D. and Zeng, X. (2000) Rural inland waterways economic impact kit: User guide. Institute for Economic Advancement, University of Arkansas at LittleRock.

Haralambides, H.E. (1996) The economic impact of shipping on the national economy. Paper presented at the International Association of Maritime Economists Conference, Vancouver, Canada.

Harrigan, F.J. and McGilvrey, J. (1988) The measurement of interindustry linkages. Ricerche Economiche 42(2): 325-343.

Hughes, W.R. (1997) A comparison of economic impacts with the use of economic base and inputoutput methodologies. Environmental Planning A 29(4): 673-684.

Jones, L.P. (1976) The measurement of Hirschmanian linkages. Quarterly Journal of Economics 90(2): 323-333.

Le Havre Port. (2000) Impact socio-economique du port. Le Havre: Le Havre Port.

Little, A.D. (1979) Port Economic Impact Kit, Arthur D. Little, Inc. and Pacific Coast Association of Port Authorities, Washington, DC: U.S. Department of Commerce, Maritime Commission.

Mangan, J., Lalwani, C. and Fynes, B. (2008) Port-centric logistics. International Journal of Logistics Management 19(1): 29-41.

Miller, R.E. and Blair, P.D. (1985) Input-Output Analysis: Foundations and Extensions. Englewood Cliffs, NJ: Prentice-Hall.

Miller, R.E. and Lahr, M.L. (eds.) (2001) A taxonomy of extractions. In: Regional Science Perspectives in Economic Analysis, A Festschrift in memory of Benjamin H. Stevens. Amsterdam, the Netherlands: North-Holland, pp. 407-441.

Moloney, R. (2004) The Economic Contribution of the Port of Cork's Cruise Ship Business to Ireland: - An Input-Output Analysis. Global Cruise.

Moloney, R. and Sjostrom, W. (2000) The Economic Value of the Port of Cork to Ireland in 1999: An Input-Output Study. Report to the Irish government. Cork: National University of Ireland.

Monte, A. (2011) Il disegno dell'indagine sul sistema portuale. In: R. Danielis (ed.) Il sistema marittimo-portuale del Friuli Venezia Giulia. Aspetti economici, statistici e storici. Trieste, Italy: EUT.

Musso, E., Benacchio, M. and Ferrari, C. (2000) Ports and employment in Port cities. Journal of Maritime Economics and Logistics 2(4): 283-312.

National Technical Information Service. (2000) Analyzing the economic impact of transportation projects using RIMS II, IMPLAN and REMI, http://ntl.bts.gov/lib/18...800/18872/PB2002102503 .pdf.

Notteboom, T. (2008) The relationship between seaports and the intermodal hinterland in light of global supply chains: European challenges. Discussion Paper 2008-2010, OECD/ITF.

Notteboom, T. (2010) Dock labour and port-related employment. ITMMA. www.espo.be.

Notteboom, T. and Rodrigue, J.-P. (2005) Port regionalization: Towards a new phase in port development. Maritime Policy Management 32(3): 297-313.

Paelinck, J., de Caevel, J. and Degueldre, J. (1965) Analyse Quantitative de Certaines Phénomènes du Développment Régional Polarisé: Essai de Simulation Statique d'itéraires de Propogation. In: Bibliotèque de l'Institut de Science Économique, No. 7, Problémes de Conversion Économique: Analyses Théoretiques et Études Appliquées. Paris: M.-Th. Génin, pp. 341-387.

Pallis, A.A., Vitsounis, T.K., De Langen, P.W. and Notteboom, T.E. (2009) A content analysis of published research in port economics, policy and management (1997-2008). International Association of Maritime Economists Conference 2009, (CD ROM) Copenhagen, Denmark.

Rasmussen, P. (1956) Studies in Intersectoral Relations. Amsterdam, the Netherlands: North-Holland.

Rietveld, P. (1994) Spatial economic impacts of transport infrastructure supply. Transportation Research A 28(4): 329-341.

Rodrigue, J.-P. and Notteboom, T. (2009) The terminalisation of supply chains: Reassessing porthinterland logistical relationships. Maritime Policy and Management 36(2): 165-183.

Salce, L. (1993) Lezioni sulle matrici. Padova, Italy: Zanichelli.

Schultz, S. (1976) Intersectoral comparisons as an approach to the identification of key sectors. In: K. Polenske and J. Skolka (eds.) Advances in Input/Output Analysis. Cambridge, MA: Ballinger.

254 (C) 2013 Macmillan Publishers Ltd. 1479-2931 Maritime Economics \& Logistics Vol. 15, 2, 222-255 
Strassert, G. (1968) Zur Bestimmung strategischer Sektoren mit Hilfe von Input-Output-Modellen. Jahrbucher fur Nationalokonomie und Statistik 182(3): 211-215.

Temple, Barker, and Sloane, Inc.. (1985) Recht Hausrath and Associates, Regional Science Research Institute, Port Economic Impact Kit. Washington, DC: Maritime Administration, Office of Port and Intermodal Development.

Urban Center of the Cleveland State University. (1997) Measuring the regional economic impact of the port of Cleveland's maritime operations.

Verbeke, A. and Dooms, M. (2008) Integrating the extended gateway concept in long-term strategic seaport planning: A European case study. Conference proceedings of the Van Horne Institute's 2007 Pacific Gateway Round Table, Canada: University of Calgary.

Vitsounis, T.K. and Pallis, A.A. (2010) Creating value for port users: Port value chains and the role of interdependencies. International Association of Maritime Economists Conference 2010, (CD ROM) Lisbon, Portugal.

Warf, B. and Cox, J. (1989) The changing economic impacts of the port of New York. Maritime Policy and Management 16(1): 3-11.

Waters, R. (1977) Port economic impact studies: Practice and assessment. Transportation Journal 17(3): 14-18.

Wilson, J.S., Mann, C.L. and Otsuki, T. (2003) Trade Facilitation and Economic Development: Measuring the Impact. Policy Research Working Paper Series 2988, The World Bank.

Yochum, G.R. and Agarwal, V.B. (1987) Economic impact of a port on a regional economy: Note. Growth and Change 18(Summer): 74-87.

Yochum, G.R. and Agarwal, V.B. (1988) Static and changing port economic impact. Maritime Policy and Management 15(2): 157-171. 